\title{
Spontan bakteriyel peritonitli hastalarda hastane içi mortaliteyi etkileyen faktörler
}

\author{
Factors affecting in-hospital mortality in patients with spontaneous bacterial peritonitis
}

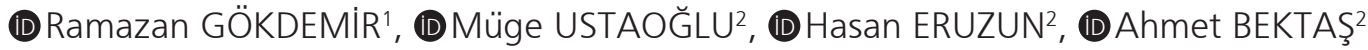 \\ Ondokuz Mayıs Üniversitesi, Tıp Fakültesi, 'İç Hastalıkları Anabilim Dalı, ${ }^{2}$ Gastroenteroloji Bilim Dalı, Samsun
}

\begin{abstract}
Giriş ve Amaç: Spontan bakteriyel peritonit, dekompanse karaciğer sirozunun sık görülen ve mortalitesi yüksek bir komplikasyonudur. Bu çalısmada spontan bakteriyel peritonitli sirotik hastalarda hastane içi mortaliteyi etkileyen faktörlerin saptanması amaçlandı. Gereç ve Yöntem: Hastanemiz Gastroenteroloji Kliniği'nde 5 yıllık periyot içinde hastanede yatan 129 sirotik hasta ve bu hastalarda gelişen 151 spontan bakteriyel peritonit epizodu retrospektif olarak değerlendirildi. Tüm hastaların demografik özellikleri, laboratuvar parametreleri, asit mayi tetkikleri, Child-Turcotte-Pugh, son dönem karaciğer hastalığı modeli, sodyum-son dönem karaciğer hastalığı modeli skorları, siroz komplikasyonları incelendi ve sağ kalan grup ile exitus olan grup bu parametreler yönünden karşılaştırıldı. Bulgular: Hastaların \%57.3'ü $(n=74)$ erkek ve $\% 42.7$ 'si $(n=55)$ kadındı, yaş ortalaması $60.4 \pm 12.7$ yıl (20 - 90) olarak bulundu. Hastalarda en sık siroz nedeni \%32.6 oranı ile hepatit B virüsü idi. Hastaların \%41.7'si Child-Turcotte-Pugh B ve \%58.3'ü Child-Turcotte-Pugh-C evresinde idi. Child-Turcotte-Pugh $C$ evresinde hastane içi mortalite oranı Child-Turcotte-Pugh B evresinde göre anlamlı olarak yüksekti $(p=0.01)$. Exitus olan grupta lökosit ve nötrofil sayısı, kan üre azotu, bilirübin, uluslararası normalleştirilmiş oran değeri ve asit mayi lökosit ve nötrofil sayısı sağ kalan gruba göre daha yüksek saptandı ( $p$ $<0.001$ ). Child-Turcotte-Pugh, son dönem karaciğer hastalığı modeli ve sodyum-son dönem karaciğer hastalı̆ı modeli skorunun hastane içi mortalite ile ilişkili olduğu ve son dönem karaciğer hastalığı modeli skorunun hastane içi mortaliteyi öngörmede sodyum-son dönem karaciğer hastalığı modeli ve Child-Turcotte-Pugh skorundan daha üstün olduğu bulundu $(p<0.001)$. Böbrek yetmezliği gelişen hastalarda hastane içi mortalite oranı daha yüksekti (\%52.7'ye karşı \%12.5; $p<0.001)$. Hepatik ensefalopati (\%48.9'a karşı \%17.3; $p<0.001)$, hepatorenal sendrom (\%85.7'ye karşı \%13.8; $p<0.001$ ) ve diğer enfeksiyonların gelişimi (\%48.5'e karşı \%21.2; $p=0.003)$ ile hastane içi mortalite arasında anlamlı ilişki saptandı. Sonuç: Spontan bakteriyel peritonitli hastalarda lökosit ve nötrofıl yüksekliği, kan üre azotu, bilirübin, uluslararası normalleştirilmiş oran, asit mayi lökosit ve asit mayi nötrofil sayısı yüksekliği hastane içi mortaliteyi olumsuz yönde etkilemektedir. Hastalarda böbrek yetmezliği gelişimi, asit mayi kültür pozitifliği, hepatik ensefalopati, hepatorenal sendrom ve enfeksiyon gelişimi hastane içi mortaliteyi arttırmaktadır. Skorlama sistemlerinden son dönem karaciğer hastalığı modeli skoru, hastane içi mortaliteyi öngörmede sodyum-son dönem karaciğer hastalı̆ı modeli ve Child-Turcotte-Pugh skorundan daha üstündür.
\end{abstract}

Anahtar kelimeler: Siroz, hastane içi mortalite, spontan bakteriyel peritonit

\footnotetext{
İletişim: Müge USTAOĞLU

Ondokuz Mayıs Üniversitesi, Tıp Fakültesi, Gastroenteroloji Bilim Dalı, Kurupelit Kampüsü, Atakum-Samsun

E-mail: ustaoglu.md@gmail.com
}

Background and Aims: Spontaneous bacterial peritonitis is a common complication of decompensated liver cirrhosis with a high mortality rate. The aim of this study was to determine the factors affecting in-hospital mortality in cirrhotic patients with spontaneous bacterial peritonitis. Materilas and Method: 129 patients with cirrhosis who were hospitalized in the Gastroenterology Clinic of our Hospital within a 5-year period and 151 episodes of spontaneous bacterial peritonitis developed in these patients were evaluated retrospectively. Demographic characteristics, laboratory parameters, ascitic fluid tests, Child-Turcotte-Pugh, Model for End-stage Liver Disease, sodium-Model for End-stage Liver Disease scores, complications of cirrhosis were examined in all patients, and the surviving group and the exitus group were compared in terms of these parameters. Results: Of the patients, $57.3 \%(n=74)$ were male and $42.7 \%(n=55)$ were female. The mean age of the patients was $60.4 \pm 12.7$ (20-90). Hepatitis $B$ virus was the most common cause of cirrhosis with a rate of $32.6 \%$. Cirrhosis stage was Child C and Child B in 58.3\% and in $41.7 \%$ of the patients respectively. In-hospital mortality rate was significantly higher in patients with Child B cirrhosis stage than those with Child C $(p=0.01)$. The leukocyte and neutrophil counts, blood urea nitrogen, bilirubin, international normalised ratio values and ascites leukocyte and neutrophil counts were found to be higher in the exitus group than the surviving group ( $p$ $<0.001)$. It was found that Child-Turcotte-Pugh, Model for End-stage Liver Disease and sodium-Model for End-stage Liver Disease scores were associated with in-hospital mortality, and Model for End-stage Liver Disease score was superior to sodium-Model for End-stage Liver Disease and Child-Turcotte-Pugh scores in predicting in-hospital mortality ( $p<$ 0.001). In-hospital mortality rate was higher in patients who developed renal failure $(12.5 \%$ versus $52.7 \% ; p<0.001)$. There was a significant relationship between in-hospital mortality and hepatic encephalopathy $(48.9 \%$ vs. $17.3 \% ; p<0.001)$, hepatorenal syndrome $(85.7 \%$ vs. $13.8 \% ; p<0.001)$, and the development of infections other than spontaneous bacterial peritonitis ( $48 \%$ vs. $\% 21,2 ; p=0.003)$. Conclusion: In patients with spontaneous bacterial peritonitis, elevated leukocytes and neutrophils, high blood urea nitrogen, bilirubin, international normalised ratio values, and high ascitic leukocytes and ascitic fluid neutrophil counts affect in-hospital mortality negatively. Development of renal failure, positive culture of ascitic fluid, hepatic encephalopathy, hepatorenal syndrome and infection other than spontaneous bacterial peritonitis increase in-hospital mortality. Of the scoring systems, the Model for End-stage Liver Disease score is superior to the sodium-Model for End-stage Liver Disease and Child-Turcotte-Pugh score in predicting in-hospital mortality.

Keywords: Cirrhosis, in-hospital mortality, spontaneous bacterial peritonitis

Gökdemir R, Ustaoğlu M, Eruzun, et al. Factors affecting in-hospital mortality in patients with spontaneous bacterial peritonitis. The Turkish Journal of Academic Gastroenterology 2021;20:150-156. DOI: 10.17941/agd.1055297

Geliş Tarihi: 06.10.2021 • Kabul Tarihi: 27.12.2021 


\section{GíRiş}

Spontan bakteriyel peritonit (SBP) asit sIvısının cerrahi olarak tedavi edilebilir bir intraabdominal kaynak olmaksızın olan enfeksiyonu olarak tanımlanır. SBP sirozlu hastalarda görülen en sık bakteriyel enfeksiyondur ve önemli morbidite ve mortalite ile ilişkilidir $(1,2)$. Bütün asitli siroz hastaları SBP için risk altındadır ve ayaktan hastalarda SBP prevalansı \%1.5 - 3.5 iken, yatan hastalarda bu oran yaklaşı \% 10'dur (3). Ayaktan dekompanse sirozlu hastalarda insidansı 1 yılda \%3.5'e ulaşır ve hastanede yatan hastalarda ise insidans \%7 ile \%30 arasında değişmektedir. SBP kötü prognoz ile ilişkilidir ve ilk epizod sonrası sağkalımın 1 yılda \%40 olduğu tahmin edilir (4). SBP tanısı temel olarak asit mayide nötrofıl sayısının 250/ $\mathrm{mm}^{3}$ ün üzerinde olması ile konulur. Asit mayi kültüründe üreme olması SBP tanısı koymak için zorunlu değildir (5).

SBP tanılı hastalarda prognozla ilişkili faktörlerin araştırıldığı farklı çalışmalarda Child-Turcotte-Pugh (CTP) ve Model for End-stage Liver Disease (MELD) skorları prognozla ilişkili bulunmuştur $(6,8,9)$. Böbrek yetmezliğinin de SBP'de prognozu belirleyen önemli faktörlerden biri olduğu gösterilmiştir (10-12).

Çalışmamızda SBP tanısı ile hastanede yatan sirotik hastalarda klinik ve laboratuvar parametrelerinin ve hastane içi mortaliteyi etkileyen faktörlerin değerlendirilmesi amaçlandı.

\section{GEREÇ ve YÖNTEM}

Çalışmamızda 5 yıllık süre içerisinde hastanemiz Gastroenteroloji Kliniği'nde yatırılan 129 siroz hastası ve bu hastalarda gelişen 151 SBP epizodu retrospektif olarak incelendi. Hastanemiz etik kurulundan 10.06.2021 tarih ve 304 numarasıyla etik kurul onayı alındı. Hastaların tamamında siroz tanısı klinik, laboratuvar, radyolojik veya histopatolojik bulgulara dayanılarak konuldu. Tüm hastaların demografik özellikleri, siroz etiyolojileri, hastaneye başvuru semptomları, laboratuvar parametreleri, asit mayi tetkikleri, CTP, MELD ve sodyum-MELD skorları incelendi.

SBP tanısı koymak için semptomatik hastalarda asit mayide nötrofil sayısının $250 / \mathrm{mm}^{3}$ ve üzerinde olması şartı arandı ve SBP tanısı konulan hastalardan alınan asit mayi kültür sonuçları incelendi. Kültür sonuçlarında üreme olanlarda üreyen etkenler kaydedildi.

Hastaların hastaneye başvuru anında veya yattıktan sonra böbrek yetmezliği gelişip gelişmediği değerlendirildi. Böbrek yetmezliği tanısı başlangıç kreatinin değeri normal olan hastalarda kreatinin değerinin 1.3 mg/dl'nin üze- rine çıkması veya başlangıç kreatinini yüksek olan veya yakın zamanda kreatinin değeri bilinmeyen hastalarda başlangıç kreatininin \%50 oranında artması ile konuldu. Ayrica hastalarda hepatorenal sendrom, özofagus varis kanaması, hepatosellüler kanser (HCC), hepatik ensefalopati ve SBP dışında gelişen diğer bakteriyel enfeksiyonlar kaydedildi.

Hastalar hastane içi dönemde sağ kalan ve exitus olan olmak üzere iki gruba ayrıldı ve iki grup tüm parametreler yönünden karşılaştırıldı.

Verilerin analizi için SPSS (Statistical package for social Sciences) paket programı kullanıldı. P $<0.05$ olması anlamlı olarak kabul edildi. Kesikli değişkenlerin grup karşllaştırmaları için Ki-Kare, sürekli değişkenlerin normal dağılım göstermediği durumlarda Mann-Whitney U testi uygulandı ve alıcı işlem karakteristikleri [Receiver Operating Characteristic (ROC)] analizi yapıldı.

\section{BULGULAR}

Çalışmaya dahil edilen 129 hastanın \%57.3'ü $(n=74)$ erkek ve \%42.7'si $(n=55)$ kadındı. Hastaların yaş ortalaması $60.4 \pm 12.7$ yıl (aralığı 23 - 90), erkek ve kadın hastaların yaş ortalaması ise sırasıyla $58.1 \pm 13.0$ ve 63.6 \pm 11.7 yll idi. Hastalarda en sık siroz nedeni \%32.6 oran ile hepatit B virüsü (HBV) idi, HBV'yi kriptojenik ve hepatit C virüsü (HCV) takip ediyordu. Hastaların \%41.7'si CTP-B, \%58.3'ü CTP-C evresindeydi. Siroz evresi CTP-A olan hasta yoktu.

Hastaların hastaneye başvuru semptomları değerlendirildi. En sık başvuru semptomu karında şişlikti. SBP epizodu geçiren hastaların hastaneye başvuru semptomları Tablo 1 'de gösterildi.

Tablo 1. SBP tanısı ile hastanede yatan hastaların başvuru semptomları

\begin{tabular}{|lc|}
\hline Bulgular & n (\%) \\
\hline Karında şişlik & $47(\% 31.1)$ \\
\hline Karın ağrısı & $26(\% 17.2)$ \\
\hline Bilinç değişikliği & $25(\% 16.6)$ \\
\hline Gis kanaması & $16(\% 10.6)$ \\
\hline Sarılık & $13(\% 8.6)$ \\
\hline Asemptomatik & $11(\% 7.3)$ \\
\hline Ateş & $7(\% 4.6)$ \\
\hline Diğer & $6(\% 4)$ \\
\hline
\end{tabular}

GIS: Gastrointestinal sistem. 
Çalışmaya dahil edilen hastaların yaşları, cinsiyetleri, tanı anındaki laboratuvar değerleri ve CTP, MELD, sodyum-MELD skorları incendi ve sağ kalan grup ile exitus olan grup bu parametreler yönünden karşılaştıııldı (Tablo 2). Exitus olan grupta serum hemoglobin, hematokrit ve serum total protein sağ kalan gruba göre anlamlı şekilde düşüktü ( $p<0.05)$, serum lökosit ve nötrofil sayısı, total ve direkt bilirübin, kan üre azotu (BUN), uluslararası normalleştirilmiş oran (INR), asit lökosit ve nötrofil sayısı ise anlamlı şekilde yüksekti $(p<0.05)$. SBP epizodu olan vakalarda hastane içi mortalite oranları Child B ve Child $C$ için sırasıyla \%17.5 ve \%34.1 olarak saptandı. CTP evresi artışının prognozu olumsuz etkilediği görüldü. CTP evresinin C olması ile hastane içi mortalite arasında istatiksel açıdan anlamlı ilişki vardı $(p=0.01)$. Sağ kalan grup ile exitus olan grubun CTP, MELD ve sodyum-MELD skorları karşılaştıııldı, exitus olan grupta her üç skor da sağ kalan gruba göre daha yüksek bulundu $(p<0.05)$ (Tablo 3$)$.

Tablo 2. Çalışma popülasyonunun özellikleri

\begin{tabular}{|c|c|c|c|c|}
\hline & $\begin{array}{l}\text { Tüm Vakalar } \\
\text { Ortalama } \pm \text { SS }\end{array}$ & $\begin{array}{c}\text { Sağ Kalanlar } \\
\text { Ortalama } \pm \text { SS }\end{array}$ & $\begin{array}{l}\text { Exitus Olanlar } \\
\text { Ortalama } \pm \text { SS }\end{array}$ & $\begin{array}{c}\text { P } \\
\text { değeri }\end{array}$ \\
\hline Yaş (yıl) & $60.4 \pm 12.7$ & $60.3 \pm 12.9$ & $60.7 \pm 12.7$ & $>0.05$ \\
\hline \multicolumn{5}{|l|}{ Cinsiyet } \\
\hline Erkek & $74(\% 57.3)$ & $55(\% 74.3)$ & $19(\% 25.7)$ & $>0.05$ \\
\hline Kadın & $15(\% 27.3)$ & $40(\% 72.7)$ & $40(\% 72.7)$ & $>0.05$ \\
\hline Hemoglobin, g/dl & $10.5 \pm 0.1$ & $10.7 \pm 0.1$ & $10.1 \pm 0.3$ & 0.018 \\
\hline Hematokrit, \% & $30.2 \pm 0.4$ & $31.1 \pm 0.4$ & $27.9 \pm 1.1$ & 0.002 \\
\hline Serum lökosit, bin/uL & $9026 \pm 505$ & $7787 \pm 481$ & $12352 \pm 1203$ & $<0.001$ \\
\hline Serum nötrofil, bin/uL & $6960 \pm 436$ & $5890 \pm 433$ & $9831 \pm 990$ & $<0.001$ \\
\hline Trombosit, bin/uL & $101834 \pm 5792$ & $98745 \pm 6989$ & $110122 \pm 10191$ & 0.1 \\
\hline INR & $1.66 \pm 0.04$ & $1.57 \pm 0.04$ & $1.9 \pm 0.1$ & 0.005 \\
\hline AST, U/L & $68.2 \pm 6.5$ & $63.1 \pm 7.9$ & $82.1 \pm 12.8$ & 0.1 \\
\hline$A L T, U / L$ & $45.2 \pm 7.0$ & $35.1 \pm 2.8$ & $72.2 \pm 24.5$ & 0.2 \\
\hline$A L P, U / L$ & $225 \pm 14$ & $229 \pm 15$ & $233 \pm 37$ & 0.1 \\
\hline GGT, U/L & $66.0 \pm 10.0$ & $56.0 \pm 6.3$ & $95.2 \pm 33.5$ & 0.5 \\
\hline Total bilirübin, mg/dl & $5.5 \pm 0.5$ & $4.2 \pm 0.5$ & $9.1 \pm 1.4$ & $<0.001$ \\
\hline Direkt bilirübin, mg/dl & $3.5 \pm 0.4$ & $2.4 \pm 0.4$ & $6.3 \pm 1.1$ & $<0.001$ \\
\hline Serum total protein, g/dl & $6.46 \pm 0.08$ & $6.55 \pm 0.08$ & $6.2 \pm 0.1$ & 0.03 \\
\hline Serum albümin, g/dl & $2.63 \pm 0.04$ & $2.67 \pm 0.05$ & $2.54 \pm 0.08$ & 0.06 \\
\hline Kalsiyum, mEq/L & $8.23 \pm 0.04$ & $8.22 \pm 0.08$ & $8.2 \pm 0.1$ & 0.6 \\
\hline Potasyum, mEq/L & $4.25 \pm 0.07$ & $4.23 \pm 0.5$ & $4.32 \pm 0.13$ & 0.7 \\
\hline Sodyum, mEq/L & $132.6 \pm 0.4$ & $133.0 \pm 0.5$ & $131.4 \pm 0.8$ & 0.06 \\
\hline BUN, mg/dl & $30.9 \pm 1.8$ & $26.0 \pm 1.8$ & $44 \pm 4$ & $<0.001$ \\
\hline Sedimentasyon, mm/saat & $30.3 \pm 2.1$ & $31.9 \pm 2.5$ & $26.0 \pm 3.9$ & 0.1 \\
\hline CRP, mg/L & $36.2 \pm 3.4$ & $32.6 \pm 3.6$ & $46.0 \pm 8.2$ & 0.5 \\
\hline Asit total protein, g/dl & $1.36 \pm 0.06$ & $1.41 \pm 0.07$ & $1.2 \pm 0.1$ & 0.06 \\
\hline Asit albümin, g/dl & $0.56+0.03$ & $0.59 \pm 0.04$ & $0.48 \pm 0.06$ & 0.09 \\
\hline Asit lökosit, bin/uL & $3232 \pm 415$ & $2627 \pm 365$ & $4855 \pm 1147$ & 0.02 \\
\hline Asit nötrofil, bin/uL & $1916 \pm 302$ & $1364+195$ & $3397 \pm 95$ & 0.009 \\
\hline
\end{tabular}

INR: Uluslararası normalleştirilmiş oran, AST: Aspartat aminotransferaz, ALT: Alanin aminotransferaz, ALP: Alkalen fosfataz, GGT: Gama glutamil transferaz, BUN: Kan üre azotu, CRP: C- reaktif protein. 
Tablo 3. SBP epizodu olan hastalarda skorlama sistemlerinin ortalama değerleri

\begin{tabular}{|lccc}
\hline Skorlamalar & Sağ Kalanlar & Exitus Olanlar & Hastane içi Mortalite $\mathbf{p}$ \\
\hline CTP & $10.0 \pm 0.1$ & $11.3 \pm 0.3$ & $\mathbf{0 . 0 0 1}$ \\
\hline MELD & $16.5 \pm 0.5$ & $23.0 \pm 1.1$ & $<\mathbf{0 . 0 0 1}$ \\
\hline Sodyum-MELD & $21.4 \pm 0.9$ & $29.7 \pm 1.5$ & $<\mathbf{0 . 0 0 1}$
\end{tabular}

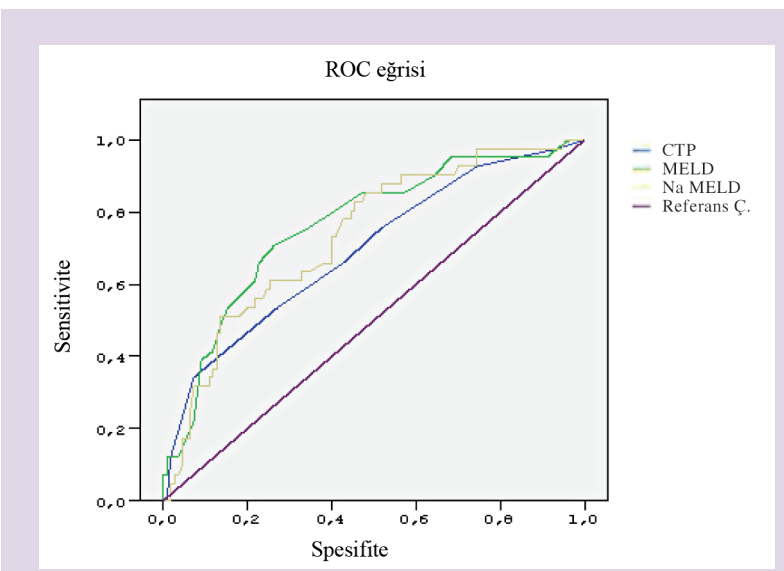

Şekil 1. CTP, MELD ve sodyum-MELD skorları için ROC eğrileri

Tüm SBP epizodu olan hastalarda CTP, MELD ve sodyum-MELD skorlarının hastane içi mortaliteye göre hesaplanan ROC eğrisi altında kalan alan (AUROC) değerleri sırasılya 0.693 (\%95 Cl: $0.576-0.771, p=0.001), 0.762$ (\%95 Cl: $0.641-0.825, p<0.001$ ), ve 0.735 olarak bulundu (\%95 Cl: 0.618 - 800, p < 0.001). Skorlama sistemlerinin ROC eğrileri Şekil 1'de gösterildi.

Hastaların yattığı dönemde gelişen veya yatışında eşlik eden siroz komplikasyonları incelendi. HCC ve özofagus varis kanaması olan hastalarda hastane içi mortalitede ar- tış yoktu $(p>0.05)$. Hepatorenal sendrom $(p<0.001)$, hepatik ensefalopati $(p<0.001)$ ve SBP dışında gelişen diğer bakteriyel enfeksiyon $(p=0.004)$ varlığında hastane içi mortalite daha yüksek saptandı (Tablo 4).

Spontan asit enfeksiyonlu tüm hastaların asit mayi kültür sonuçları incelendi. Hastaların \%26.5'inde asit mayi kültüründe üreme saptandı. Asit mayi kültürlerinde en fazla izole edilen etken \%40 oranında Escherichia coli iken, bunu \%20 oranında Klebsiella ve \%17.5 oranında Streptokok spp izledi. Asit mayi kültüründe üreme olup olmaması ile hastane içi mortalite arasındaki ilişki araştırıldı. Asit kültüründe üreme olan ve olmayan hastalar için mortalite oranları sırasıly $\% 47.5$ ve \%19.9 olarak bulundu. Asit mayi kültüründe üreme olan hastalarda hastane içi mortalite üreme olmayanlara göre istatistiksel olarak anlamlı yüksekti $(p=0.002)$. Asit kültüründe izole edilen etkenin başlanan antibiyotiğe duyarlı veya dirençli olması ile prognoz arasındaki ilişki değerlendirildi. İzole edilen etkenin antibiyotik duyarlı ve dirençli olan vakalarda hastane içi mortalite oranı sırasıyla \%29.2 ve \%75 olarak bulundu. Asit kültüründe izole edilen etkenlerin antibiyotik dirençli olması durumunda hastane içi mortalite istatistiksel açıdan anlamlı olarak yüksek saptandı $(p<0.05)$.

Böbrek yetmezliği gelişimi ile mortalite arasındaki ilişki araştıııldı. Hastanede yattığı süre içerisinde exitus olan hastaların \%70.7'sinde böbrek yetmezliği vardı. Ayrıca

\section{Tablo 4. SBP'li hastalarda siroz komplikasyonları ve hastane içi mortalite arasındaki iliş̧ki}

\begin{tabular}{|c|c|c|c|c|}
\hline Komplikasyonlar & & n (\%) & Mortalite Oranı & $\mathbf{p}$ \\
\hline \multirow[t]{2}{*}{ Hepatosellüler karsinom } & Var & $25(\% 16.6)$ & $\% 40$ & $>0.05$ \\
\hline & Yok & $126(\% 83.4)$ & $\% 24.6$ & \\
\hline \multirow[t]{2}{*}{ Özofagus varis kanaması } & Var & $17(\% 11.3)$ & $\% 41.2$ & $>0.05$ \\
\hline & Yok & $134(\% 88.7)$ & $\% 25.4$ & \\
\hline \multirow[t]{2}{*}{ Hepatorenal sendrom } & Var & $28(\% 18.5)$ & $\% 85.7$ & $<0.001$ \\
\hline & Yok & $123(\% 81.5)$ & $\% 13.8$ & \\
\hline \multirow[t]{2}{*}{ Hepatik ensefalopati } & Var & $47(\% 31.1)$ & $\% 48.9$ & $<0.001$ \\
\hline & Yok & $104(\% 68.9)$ & $\% 17.3$ & \\
\hline \multirow[t]{2}{*}{ Diğer enfeksiyonlar } & Var & $33(\% 21.9)$ & $\% 48.5$ & 0.003 \\
\hline & Yok & $118(\% 78.1)$ & $\% 21.2$ & \\
\hline
\end{tabular}


böbrek yetmezliği gelişen ve böbrek yetmezliği olmayan hastalarda hastane içi mortalite oranı sırasıyla \%52.7 ve $\% 12.5$ olarak saptandı $(p<0.001)$.

\section{TARTIŞMA}

SBP, sirozlu hastalarda görülen ciddi morbidite ve mortaliteye neden olan önemli bir komplikasyondur. Literatüre göre SBP gelişen hastaların \%29' u 1 yıl içinde ölmektedir (27). Bu nedenle SBP tanısı olan hastalarda mortaliteyi etkileyen faktörlerin saptanması önemlidir.

Literatürde SBP tanıı hastaların çoğunluğunun erkek cinsiyet ve siroz etiyolojisinin en sık HBV $(8,9)$ olduğu bildirilmiş olup, cinsiyet, siroz etiyolojisi ve yaş ile mortalite arasında anlamlı ilişki bulunmamıştır (8-10). Niu ve arkadaşları tarafından yapılan geniş katııımlı bir çalışmada kadın cinsiyet ve ileri yaş artmış hastane içi mortalite ile ilişkili bulunmuştur (2). Bizim çalışmamızda ise SBP'li hastalarda siroz etiyolojisi en sık HBV olup, hastaların çoğunluğunu erkek cinsiyet oluşturmaktaydı. Yaş ve cinsiyet yönünden sağ kalan ve exitus olan grup karşılaştırıldığında aralarında anlamlı bir fark saptanmadı ( $p>0.05)$.

SBP tanılı hastalarda yapılan çalışmalarda bilirübin, INR, aspartat aminotransferaz ve glukoz gibi çeşitli laboratuvar parametreleri mortalite ile ilişkili bulunmuştur $(26,27)$. Khan ve arkadaşları tarafından, siroz tanısı ve enfeksiyonu olan hastalarda yapılan bir çalışmada beyaz küre, nötrofil, $B U N$, kreatinin, total protein, gama glutamil transferaz (GGT) ve albümin değerlerinin mortalite ile ilişkili olduğu saptanmıştır (16). Serum sodyumu siroz ve kronik karaciğer hastalı̆ı olan hastalarda mortalite için prediktif bir faktördür (17-19). Jenq ve arkadaşları tarafından yapılan bir çalışmada siroz tanısı olan hastalar sodyum değerlerine göre; sodyum değeri 135 mEq/L'den küçük olanlar ve $135 \mathrm{mEq} / \mathrm{L}^{\prime} y e$ eşit ve büyük olanlar olarak iki gruba ayrımış ve hiponatremi ile hastane içi mortalite arasında anlamlı ilişki bulunmuşken (20), Song ve arkadaşları tarafından yapılan çalışmada ise SBP tanılı siroz hastalarında hastane içi mortalite ile hiponatremi arasında anlamlı ilişki saptanmamışıı (11). Yine Kim ve arkadaşları tarafından yapılan, HBV'ye bağlı sirozu olan SBP'li hastalarda hastane içi mortalite ile hiponatremi arasında ilişki bulunmamışır (21). Çalışmamızda hastane içi mortalite gelişen grupta sağ kalan gruba göre hemoglobin, hematokrit ve total protein daha düşük, lökosit, nötrofil, BUN, total ve direkt bilirübin, INR, asit mayi lökosit ve nötrofil ise daha yüksek saptandı $(p<0.05)$, serum sodyum değerinde ise iki grup arasında anlamlı bir farklılık saptanmadı.

SBP tanısını destekleyen klinik bulguları olan ve asit mayide nötrofıl sayısında artış bulunan hastaların \%60'ında asit mayi kültürlerinde üreme olmamaktadır (26). Gram negatif bakteriler, Escherichia coli ve Klebsiella spp. en sık izole edilen organizmalardır. Ancak, sirozlu hastalarda gram pozitif, kinolona dirençli ve çoklu ilaca dirençli bakteri prevalansının artmasıyla son dekatta enfeksiyonların bakteriyolojisinde büyük değişiklikler meydana gelmiştir ve gram pozitif bakterilerin prevelansında artış bildirilmiştir. En sık görülen gram pozitif bakteriler Streptococcus spp., Enterococcus spp. ve Staphylococcus spp'dır $(28,29)$. Çalışmamızda hastaların $\% 26.5^{\prime}$ inde asit mayi kültüründe üreme saptandı ve en fazla üreyen etkenler sırayla Escherichia coli, Klebsiella ve Streptokok spp idi. Asit mayi kültür pozitifliği ile mortalite arasında anlamlı ilişki bulundu. Asit mayi kültüründe üreme oranı literatürde bildirilenden daha düşük bulundu. Üreme oranımızın düşüklüğünün, hastaların enfeksiyonun ileri dönemlerinde başvurmasına, enflamatuvar süreci tetikleyenin bakteri DNA'sı olmasına, tanı anında hemen kültür alınmamasına veya kültür alımındaki teknik hatalara bağlı olabileceği düşünüldü.

Klinik ve laboratuvar parametrelerine dayanarak sirozlu hastaların prognozunu belirlemede en sık kullanılan CTP, MELD ve sodyum-MELD skorlama sistemleridir. Ilerlemiş sirozlu hastalarda bakteriyel translokasyonun arttığı gösterilmiştir $(30,31)$. SBP'li hastaların çoğunda ciddi karaciğer disfonksiyonu vardır ve \%96'sı CTP sınıflamasına göre $B$ ya da $C$ evresindedir $(7,12,14)$. CTP sınıflamasının, Filik ve arkadaşlarının yaptığı çalışmada hastane içi mortalite tayininde anlamlı olduğu bulunmuştur (19). Ayrıca Tüzün ve arkadaşlarının yaptığı çalışmada da CTP skoru kısa dönem mortalite için prediktif değer olarak bildirilmiştir (9). Yine Song ve arkadaşlarının yaptığı çalışmada CTP-C evresi ile kısa dönem ve ilk 6 aylık mortalite arasında anlamlı ilişki saptanmıştır (11). Çalışmamızda SBP epizodu geçiren siroz hastalarının \%58.3'ü CTP-C evresinde olup hastaların çoğunluğunu oluşturmaktaydı ve siroz evresinin CTP sınıflamasına göre C olması ile hastane içi mortalite arasında anlamlı ilişki bulundu. Heo ve arkadaşları ile Nobre ve arkadaşlarının yaptıkları iki farklı çalışmada MELD skorunun SBP tanısı olan sirozlu hastalarda hastane içi mortalitenin belirlenmesinde bağımsız prediktif bir faktör olduğu bildirilmiştir $(22,23)$. Ayrıca Cho ve arkadaşlarının yaptığı bir çalışmada da benzer şekilde SBP tanısı olan sirozlu hastalarda mortalite tayininde MELD skoru prediktif bir değer olarak bulunmuştur (8). Bizim çalışmamızda da MELD skoru ile hastane içi mortalite arasında istatiksel açıdan anlamlı bir ilişki bulundu. Bir diğer skorlama sistemi olan sodyum-MELD ile ilgili yapılan sınırlı sayıda çalışmada sodyum-MELD skorunun hastane içi mortaliteyi tahmin etmede önemli olduğu bildirilmiştir $(24,26)$. Bizim çalışmamızda da sodyum-MELD skoru yüksekliği ile hastane içi mortalite arasında anlamlı bir ilişki saptandı. 
Ayrıca hastane içi mortalite tayini açısından yapılan ROC analizinde MELD skoru AUROC'u sodyum-MELD ve CTP skorlarınınkinden daha büyüktü ve bu da MELD skorunun hastane içi mortaliteyi öngörmede, sodyum-MELD ve CTP skorundan daha üstün olduğunu gösterdi.

SBP tanısı olan hastalarda prognoz üzerinde siroz komplikasyonlarının etkisini inceleyen Filik ve arkadaşlarının yaptığı bir çalışmada SBP tanısı olan sirozlu hastalarda hepatik ensefalopati, SBP birlikteliğinde sekonder enfeksiyon gelişmesi ve renal fonksiyonlarda bozulma hastane içi mortalite ile ilişkili bulunmuştur (15). Tüzün ve arkadaşları tarafından yapılan çalışmada ise hastane içi mortalite ile hepatorenal sendrom, hepatik ensefalopati ve özofagus varis kanaması arasında anlamlı ilişki bulunmuştur (9). Morino Rodriguez ve arkadaşları tarafından yapılan SBP tanısı olan sirozlu hastalarda prognostik değerlerin araştırıldığı bir başka çalışmada hepatik ensefalopati, renal fonksiyonlarda bozulma ve HCC hastane içi mortalite ile ilişkili bulunmuştur (25). Çalışmamızda hastane içi mortalite gelişen grupta hepatorenal sendrom, hepatik ensefalopati ve SBP dışında gelişen diğer bakteriyel enfeksiyon görülme sıklığı sağ kalan gruba göre daha fazla idi.

Yapılan birçok çalışmada SBP tanısı olan hastalarda renal fonksiyon bozukluğunun mortalite için prediktif bir gösterge olduğu saptanmıştır $(7,11,13,15)$. Tandon ve arkadaşları tarafından yapılan SBP tanısı olan siroz hastalarında hastane içi veya 30 günlük mortaliteyi değerlendiren
18 çalışmanın incelendiği bir metanalizde renal disfonksiyon gelişen hastalarda mortalite oranı $\% 67$ iken renal disfonksiyon gelişmeyen hastalarda mortalite oranı \%11 olarak bulunmuştur (32). Follo ve arkadaşlarının yaptığı çalışmada SBP epizodu geçiren tüm hastaların \%33'ünde renal fonksiyon bozukluğu geliştiği görülmüş ve SBP tanılı sirozlu hastalarda böbrek yetmezliği gelişiminin mortalitenin çok güçlü bir göstergesi olduğu saptanmıştır (12). Çalışmamızda hastaların \%36.4'ünde böbrek yetmezliği gelişti. Böbrek yetmezliği gelişen hastalarda mortalite oranı \%52.7 iken, böbrek yetmezliği olmayan hastalarda mortalite oranı \%12.5 olarak bulundu. Böbrek yetmezliği gelişimi mortalite için prediktif bir değer olarak bulundu ve bu bulgu literatürle uyumluydu.

Sonuç olarak çalışmamızda SBP tanılı hastalarda CTP, MELD ve sodyum-MELD skorlarının üçünün de hastane içi mortaliteyi öngörmede etkili olduğu ve MELD skorunun CTP ve sodyum-MELD skorundan daha üstün olduğu saptanmıştır. Ayrıca hastalarda böbrek yetmezliği gelişmesi ve asit mayi kültüründe üreme olması hastane içi mortaliteyi arttırmaktadır.

Etik Kurul Onayı: Çalışmamız Ondokuz Mayıs Üniversitesi Klinik Araştırmalar Etik Kurulunun 10.06.2021 tarih ve 304 nolu kararına bağı olarak gerçekleştirilmiştir.

Çıkar Çatışması Beyanı: Yazarlar herhangi bir çıkar çatışması beyan etmemektedir.

\section{KAYNAKLAR}

1. Schwabl P, Bucsics T, Soucek K, et al. Risk factors for development of spontaneous bacterial peritonitis and subsequent mortality in cirrhotic patients with ascites. Liver Int 2015;35:2121-8.

2. Niu B, Kim B, Limketkai BN, et al. Mortality from spontaneous bacterial peritonitis among hospitalized patients in the USA. Dig Dis Sci 2018;63:1327-33

3. European Association for the Study of the Liver. EASL Clinical Practice Guidelines for the management of patients with decompensated cirrhosis. J Hepatol 2018;69:406-60. Epub 2018 Apr 10. Erratum in: J Hepatol 2018;69:1207.

4. Marciano S, Díaz JM, Dirchwolf M, Gadano A. Spontaneous bacterial peritonitis in patients with cirrhosis: incidence, outcomes, and treatment strategies. Hepat Med 2019;11:13-22.

5. European Association for the Study of the Liver. EASL clinical practice guidelines on the management of ascites, spontaneous bacterial peritonitis, and hepatorenal syndrome in cirrhosis. J Hepatol 2010;53:397-417

6. Oliveira AM, Branco JC, Barosa R, et al. Clinical and microbiological characteristics associated with mortality in spontaneous bacterial peritonitis: a multicenter cohort study. Eur J Gastroenterol Hepatol 2016;28:1216-22.

7. Thanopoulou AC, Koskinas JS, Hadziyannis SJ. Spontaneous bacterial peritonitis (SBP): clinical, laboratory, and prognostic Features $A$ singlc-center experience. Eur J IntMed 2002;13:194-8.

8. Cho JH, Park KH, Kim SH, et al. Bacteremia is aprognostic factor for poor outcome in spontaneous bacterial peritonitis. Scand J Infect Dis 2007;39:697-702.

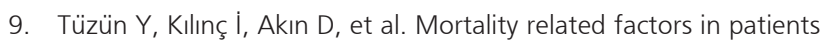
with spontaneous bacterial peritonitis Dicle Tıp Dergisi 2008;35):105.

10. Perdomo Coral G, Alves de Mattos. A Renal impairment after spontaneous bacterial peritonitis: incidence and prognosis. Can J Gastroenterol 2003;17:187-90.

11. Song JY, Jung SJ, Park CW, et al. Prognostic signiflcance of infeetion acquisition sites in spontaneous bacterial peritonitis: nosocomial versus community acquired. J Korean Med Sci 2006;21:666-71.

12. Follo A, Llovet JM, Navasa M, et al. Renal impairment after spontaneous bacterial peritonitis in cirrhosis: incidence, clinical course, predictive factors and prognosis. Hepatology 1994;20:1495-501.

13. Cheong $\mathrm{HS}$, Kang $\mathrm{Cl}$, Lee $\mathrm{JA}$, et al. Clinical signiflcance and outcome of nosocomial acquisition of spontaneous bacterial peritonitis in patients vvith liver cirrhosis. Clin Infect Dis 2009;48:1230-6.

14. Toledo C, Salmeron JM, Rimola A, et al. Spontaneous bacterial peritonitis in cirrhosis: predictive factors of infection resolution and survival in patients treated with cefotaxime. Hepatology 1993;17:2517.

15. Filik L, Unal S. Clinical and laboratory Features of Spontaneous Bacterial Peritonitis. E ast Afr Med J 2004;81:474-9. 
16. Khan R, Abid S, Jafri W, et al. Model for end-stage liver disease (MELD) score as a usefill prognostic marker in cin'hotic patients with infection. J Coll Physicians Surg Pak 2009;19):694-8.

17. Wong VW, Chim AM, Wong GL, et al. Performance of the new MELD-Na score in predicting 3-month and 1-year mortality in Chinese patients with chronic hepatitis B. Liver Transpl 2007;13:1228-35.

18. Wang YW, Huo TI, Yang YY, et al. Correlation and comparison of the model for end-stage liver disease, portal pressure, and serum sodium for outcome prediction in patients with livercirrhosis. J Clin Gastroenterol 2007;41:706-12.

19. Selçuk H, Uruc I, Temel MA, et al. Factors prognostic of survival in patients awaiting liver transplantation for end-stage liver disease. Dig Dis Sci 2007;52:3217-23.

20. Jenq CC, Tsai MH, Tian YC, et al. Serum sodium predicts prognosis in critically ili cirrhotic patients. Clin Gastroenterol 2010;44:220-6.

21. Kim SU, Chon YE, Ece CK, et al. Spontaneous bacterial peritonitis in patients with hepatitis B virus-related liver cirrhosis: community-acquired versus nosocomial. Yonsei Med J 2012;53:328-36.

22. Heo J, Seo YS, Yim HJ, et al. Clinical features and prognosis of spontaneous bacterial peritonitis in Korean patients with liver cirrhosis: a multicenter retrospective study. Gut Liver 2009;3:197204.

23. Nobre SR, Cabral JE, Gomes JJ, et al. In-hospital mortality in spontaneous bacterial peritonitis: a new predictive model. Eur J Gastroenterol Hepatol 2008;20:1176-81.

24. Musskopf MI, Fonseca FP, Gass J, et al. Prognostic factors associated with in-hospital mortality in patients with spontaneous bacterial peritonitis. Ann Hepatol 2012;11:915-20.
25. Merino Rodriguez B, Nunez Martinez O, Diaz Sânchez A, et al. Prognostic value of a spontaneous bacterial peritonitis episode in cirrhotic patients in clinical practice. Gastroenterol Hepatol 2008;31:560-5

26. Bal CK, Daman R, Bhatia V. Predictors of fifty days in-hospital mortality in decompensated cirrhosis patients with spontaneous bacterial peritonitis. World J Hepatol 2016;8:566-72.

27. Tsung PC, Ryu SH, Cha IH, et al. Predictive factors that influence the survival rates in liver cirrhosis patients with spontaneous bacterial peritonitis. Clin Mol Hepatol 2013;19:131-9.

28. Caraceni P, Riggio O, Angeli P et al; ANSWER Study Investigators. Long-term albumin administration in decompensated cirrhosis (ANSWER): an open-label randomised trial. Lancet 2018:391:2417-29. Erratum in: Lancet 2018;392:386.

29. Piano S, Brocca A, Mareso S, Angeli P. Infections complicating cirrhosis. Liver Int 2018;38(Suppl 1):126-33.

30. Cirera I, Bauer TM, Navasa M, et al. Bacterial translocation of enteric organisms in patients with cirrhosis. J Hepatol 2001;34:32-7.

31. Casafont F, Sánchez E, Martín L, Agüero J, Romero FP. Influence of malnutrition on the prevalence of bacterial translocation and spontaneous bacterial peritonitis in experimental cirrhosis in rats. Hepatology 1997;25:1334-7.

32. Tandon $P$, Kumar D, Seo YS, et al. The 22/11 risk prediction model: a validated model for predicting 30-day mortality in patients with cirrhosis and spontaneous bacterial peritonitis. Am J Gastroenterol 2013;108:1473-9. 